\title{
Particle Sizes and Wood/Cement Ratio Effect on the Production of Vibro-compacted Composites
}

\author{
Vinicius Castro ${ }^{1}$, Carlos Parchen ${ }^{2}$, Setsuo Iwakiri ${ }^{2}$ \\ ${ }^{1}$ Universidade Federal Rural do Semi-Árido - UFERSA, Mossoró/RN, Brasil \\ ${ }^{2}$ Universidade Federal do Paraná - UFPR, Curitiba/PR, Brasil
}

\begin{abstract}
The aim of this study was to evaluate the influence of particle size and the wood/cement ratio on the physical and mechanical properties of vibro-compacted wood-cement composites. The effects of three different particle sizes (diameter between 1.4-2.36 mm; 2.36-4 mm; and 4-9.56 mm) and wood:cement ratios of 1:2.75, 1:2 and 1:1.5 on wood-cement composites produced with the Amazonia species Swartzia recurva Poepp. and Portland cement type II-Z were analyzed. All evaluated properties were influenced by the particle size used in the mixture; however, the wood:cement ratio only affected the final density of the composite, internal bond and water absorption properties. Composites produced with particles that pass through a $2.36 \mathrm{~mm}$ screen but were retained with a $1.4 \mathrm{~mm}$ screen showed average values of modulus of rupture and higher modulus of elasticity than composites produced with bigger particles. The use of a 1:2.75 wood:cement ratio resulted in composites with higher density and dimensional stability than composites produced with a lower amount of cement.
\end{abstract}

Keywords: Amazonian species, Swartzia recurva, wood-cement composites. 


\section{INTRODUCTION}

Most Swartzia Schreber species occur in tropical regions of Central and South America, and can often be found in the Amazon region, its center of dispersion (Angyalossy-Alfonso \& Miller, 2002). Steege et al. (2006) reported that Swartzia genera is one of the ten most common in the Amazon region. Physical and mechanical properties make Swartzia recurva timber a potential material for the wood industry; however, this creates a new problem due to residue generation, as according to Pereira et al. (2010), the average yield rate in the wood industry processes in the Amazon region is only 41\%.

As suggested by Parchen et al. (2016), wood-cement composites produced by vibro-dynamic compression are an alternative use for slabs, which are a major sawmill residue. The method is simple and cheap, as there is no need for complex equipment or high cost implementation. However, some variables of this new methodology raise questions due to the process particularities that usually do not occur in traditional wood-cement composite manufacturing using hydraulic presses. Examples of these variables are the ideal cement/wood ratio and the most viable wood particle size to be accommodated during the vibration process.

The wood/cement ratio used in composites must balance the product's final density and its physical and mechanical properties. Fuwape \& Oyagade (1993) studied the relation between wood/cement ratio and static bending properties of traditional wood-cement composites produced with tropical timber, and observed that average values of modulus of rupture (MOR) and elasticity (MOE) were higher when a 1:2.3 wood/cement ratio was used in high density composites (between 1 and $1.4 \mathrm{~g} \mathrm{~cm}^{-3}$ ). However, when the composite target density was $0.8 \mathrm{~g} \mathrm{~cm}^{-3}$, the results were not statistically different from composites that used less cement with a wood/cement ratio of 1:1.5.

Traditionally, the particle size used in wood-cement composite production can be correlated with the degree of wood and cement particle bonding (Olorunnisola, 2009). Wood-cement composites usually require larger wood particle sizes than are used in particleboard production to ensure economic viability of the final product. In addition to higher energy costs to generate smaller particles (which become even higher due to the high density of tropical hardwood), the smaller the particle, the higher the surface area, and consequently the greater the quantity of bonding material required (Frybort et al., 2008).

The aim of this study was to evaluate the influence of particle size and wood/cement ratio on the physical and mechanical properties of wood-cement composites produced by vibro-compaction.

\section{MATERIAL AND METHODS}

Slabs were obtained from log sawing of Swartzia recurva Poepp. (density: $0.8 \mathrm{~g} \mathrm{~cm}^{-3}$ ) at a sawmill located in Manaus, AM, Brazil. The material was debarked and kept submerged in cold water for 7 days. The water was changed daily to stimulate extraction of substances that could negatively influence cement setting.

Particles were generated in a disk chipper, dried to a moisture content of approximately $3 \%$, reprocessed in a hamermill, separated by automatic sieving and classified as P1 (particles that passed through a $2.36 \mathrm{~mm}$ sieve but were retained in a $1.4 \mathrm{~mm}$ sieve), P2 (particles that passed through a $4 \mathrm{~mm}$ sieve but were retained in a $2.36 \mathrm{~mm}$ sieve) and P3 (particles that passed through a $9.52 \mathrm{~mm}$ sieve but were retained in a $4 \mathrm{~mm}$ sieve).

Wood-cement composites were produced by vibro-dynamic compaction method, as suggested by Parchen et al. (2016). Fresh Portland CP II-Z cement was used. Composites were produced with three wood/cement ratios: 1:2.75, 1:2 and 1:1.5 (based on oven dry weight).

The amount of water used in the mixture was determined by an adjustment to the formula suggested by Simatupang (1979) for producing traditional wood-cement composites. An extra 15\% water was added based on dry cement weight. This adjustment was necessary due to the lack of pressure in the vibro-compaction, which is different from the traditional method as the water inside the wood particle became unavailable for the cement setting.

Three percent $(3 \%)$ calcium chloride $\left(\mathrm{CaCl}_{2}\right)$ based on cement weight was added to the mixture as a cement accelerator. The mixtures were deposited on prismatic plywood molds with dimensions $420 \mathrm{~mm}$ long, $70 \mathrm{~mm}$ wide and $15 \mathrm{~mm}$ high. The molds were placed on a vibration table with an equivalent impact load of $220 \mathrm{~N}$ at $3,000 \mathrm{rpm}$. 
The molds were totally filled with the wood-cement mixture and submitted to vibration for 30 seconds. After the initial material accommodation, an extra amount of mixture was deposited, and vibration was applied once again for 30 seconds. This process was repeated until there was no free space available in the prismatic mold, even after vibration. Three samples were manufactured for each treatment.

The specimens were kept in the molds for 7 days. After this period, the molds were disassembled and the composites remained in an outdoor environment for 21 days, totaling a cure period of 28 days prior to the performance tests. Then the samples were cut by a diamond saw to meet the dimensions required by the European Standard (CEN) for static bending (CEN, 1993a); water absorption and thickness swelling (CEN, 1993b); and for internal bonding (CEN, 1993c).

The experimental design was completely randomized by factorial design to examine the relationship between the two factors of particle size and wood/cement ratio. The treatment effects on the composite properties were evaluated by analysis of variance (ANOVA), considering the composite density as a covariate. When statistical differences between means were observed, the Tukey test $(\mathrm{p}<0.05)$ was applied with sliced interactions.

\section{RESULTS AND DISCUSSION}

Table 1 shows the analyses of variance for physical and mechanical properties of wood-cement composites.

The composites' density and internal bonding were influenced by particle size, wood/cement ratio, and the interaction of these factors. However, static bending properties were only affected by particle size. Properties related to the material dimensional stability were influenced by particle sizes and the interaction between particle size and wood/cement ratio. However, only water absorption after 24 hours of immersion was sensitive to different wood/cement mixture ratios.

Composite densities produced with different wood/cement ratios and particle sizes are shown in Table 2.

Treatments produced with P1 particles showed a final density directly correlated to the amount of cement added to the mixture. Composites with 1:2.75 wood/cement ratio had a statistically higher density than those produced with 1:2 ratio. On the other hand, the mean density of a 1:2 ratio composite, was statistically higher than the 1:1.5 ratio samples. Moreover, composites produced with different particle sizes did not show statistical difference between density average values when a 1:2 or 1:1.5 wood/cement ratio was used.

Table 1. Summary of analysis of variance for physical and mechanical properties of wood-cement composites.

\begin{tabular}{|c|c|c|c|c|}
\hline \multirow{2}{*}{ Variation source } & \multirow{2}{*}{ Degrees of freedom } & \multirow{2}{*}{$\frac{\text { Density }}{\text { Mean square }}$} & \multicolumn{2}{|c|}{ Water absorption } \\
\hline & & & 2 hours & 24 hours \\
\hline Particle size (A) & 2 & $0.040^{* *}$ & $292.290^{* *}$ & $289.777^{\star \star}$ \\
\hline $\mathrm{W} / \mathrm{C}$ ratio $(\mathrm{B})$ & 2 & $0.035^{\star *}$ & $5.8524^{\mathrm{NS}}$ & $20.766^{*}$ \\
\hline$(\mathrm{AxB})$ & 4 & $0.027^{\star *}$ & $45.819^{* *}$ & $22.260^{* *}$ \\
\hline Residue & 39 & 0.003 & 2.015 & 2.531 \\
\hline \multirow{2}{*}{ Variation source } & \multirow{2}{*}{ Degrees of freedom } & Thickness Swelling & \multirow{2}{*}{2 hours } & \multirow{2}{*}{24 hours } \\
\hline & & Mean square & & \\
\hline Particle size (A) & 2 & $0.106^{*}$ & & $0.130^{*}$ \\
\hline $\mathrm{W} / \mathrm{C}$ ratio $(\mathrm{B})$ & 2 & $0.008^{\mathrm{NS}}$ & & $0.002^{\mathrm{NS}}$ \\
\hline$(\mathrm{AxB})$ & 4 & $0.010^{\star \star}$ & & $0.181^{\star *}$ \\
\hline Residue & 39 & 0.022 & & 0.027 \\
\hline \multirow{2}{*}{ Variation source } & \multirow{2}{*}{ Degrees of freedom } & IB & \multirow{2}{*}{ MOR } & \multirow{2}{*}{ MOE } \\
\hline & & Mean square & & \\
\hline Particle size (A) & 2 & $0.150^{\star \star}$ & $6.844^{* *}$ & $7273992^{\star *}$ \\
\hline $\mathrm{W} / \mathrm{C}$ ratio $(\mathrm{B})$ & 2 & $0.031^{*}$ & $0.010^{\mathrm{NS}}$ & $18869^{\mathrm{NS}}$ \\
\hline$(\mathrm{AxB})$ & 4 & $0.036^{* *}$ & $0.128^{\mathrm{NS}}$ & $510991^{\mathrm{NS}}$ \\
\hline Residue & 39 & 0.008 & 0.205 & 254740 \\
\hline
\end{tabular}

${ }^{*}$ Significant at $1 \%(\mathrm{p}<0.01)$; ${ }^{*}$ Significant at $5 \%(0.01>\mathrm{p}<0.05)$; ${ }^{\text {NS}}$ Not significant at $5 \%(\mathrm{p}>0.05)$; IB = internal bonding; $\mathrm{MOR}=$ modulus of rupture; $\mathrm{MOE}=$ modulus of elasticity. 
P2 and P3 particles (the ones with higher dimensional values, and therefore with lower superficial area) absorbed less water during the mixture resulting in an excessive liquid mixture. Part of the material was lost during the vibration process, as the liquid mixture drained through the mold's gaps. Therefore, the amount of cement presented in the composites produced with bigger particles was actually lower than the supposed wood/cement ratio of the initial mixture.

The effect of the interaction between wood/cement ratio and particle size in the final density of the composites could be observed in two cases; when 1:1.25 wood/cement ratio was used, average density of P1 composites was statistically higher than P3 composites. However, the composite density behavior for the 1:1.5 ratio was different. P1 composites had a statistically lower density value than $\mathrm{P} 2$ composites.
Table 3 shows values of mechanical properties for composites produced with different wood/cement ratios and particle sizes.

There was no statistical difference between the average internal bonding values of composites produced with different wood/cement ratios when the same particle size was used. However, P1 composites had statistically similar values to $\mathrm{P} 2$ composites and higher values than P3 composites, regardless of the wood/cement ratio implemented.

According to Ashori et al. (2012), composites produced by the traditional press method with a higher amount of wood particles present a greater number of wood-to-wood bonds, without agglutinant material, thus resulting in lower internal bonding values. In the case of vibro-compacted composites, wood particles were accommodated during vibration, thereby creating

Table 2. Density of wood-cement composites made with different particle sizes and wood/cement ratios.

\begin{tabular}{|c|c|c|c|c|}
\hline & \multirow[b]{2}{*}{ Wood/Cement ratio } & \multicolumn{3}{|c|}{ Particle size } \\
\hline & & $\begin{array}{c}\text { P1 } \\
(1.4-2.36 \mathrm{~mm})\end{array}$ & $\begin{array}{c}\text { P2 } \\
(2.36-4 \mathrm{~mm})\end{array}$ & $\begin{array}{c}\text { P3 } \\
(4-9.52 \mathrm{~mm})\end{array}$ \\
\hline \multirow{3}{*}{$\begin{array}{l}\text { Density } \\
\left(\mathrm{g} \mathrm{cm}^{-3}\right)\end{array}$} & $1: 2.75$ & $\begin{array}{l}1.14^{\mathrm{Aa}} \\
(4.52)\end{array}$ & $\begin{array}{l}1.09^{\mathrm{ABa}} \\
(4.42)\end{array}$ & $\begin{array}{l}1.03^{\mathrm{Ba}} \\
(7.20)\end{array}$ \\
\hline & $1: 2.0$ & $\begin{array}{l}0.90^{\mathrm{Ab}} \\
(4.64)\end{array}$ & $\begin{array}{l}0.91^{\mathrm{Ab}} \\
(5.13)\end{array}$ & $\begin{array}{c}0.76^{\mathrm{Bb}} \\
(11.01)\end{array}$ \\
\hline & $1: 1.15$ & $\begin{array}{l}0.70^{\mathrm{BC}} \\
(5.55)\end{array}$ & $\begin{array}{l}0.83^{\mathrm{Ab}} \\
(3.13)\end{array}$ & $\begin{array}{c}0.77^{\mathrm{ABb}} \\
(8.30)\end{array}$ \\
\hline
\end{tabular}

Means followed by same capital letter in the same column do not differ statistically by Tukey test $(\mathrm{p}<0.05)$. Means followed by same lowercase letter in the same line do not differ. Values inside parentheses are the coefficient of variation (\%). P1 = particles that passed through a $2.36 \mathrm{~mm}$ sieve but were retained in a $1.4 \mathrm{~mm}$ sieve; $\mathrm{P} 2=$ particles that passed through a $4 \mathrm{~mm}$ sieve but were retained in a $2.36 \mathrm{~mm}$ sieve; $\mathrm{P} 3$ = particles that passed through a $9.52 \mathrm{~mm}$ sieve but were retained in a $4 \mathrm{~mm}$ sieve.

Table 3. Average values for mechanical properties of wood-cement composites produced with different particle sizes and wood/cement ratios.

\begin{tabular}{|c|c|c|c|c|}
\hline \multirow{2}{*}{$\begin{array}{l}\text { Mechanical } \\
\text { Properties }\end{array}$} & \multirow[b]{2}{*}{ Wood/cement ratio } & \multicolumn{3}{|c|}{ Particle size } \\
\hline & & $\begin{array}{c}\text { P1 } \\
(1.4-2.36 \mathrm{~mm})\end{array}$ & $\begin{array}{c}\text { P2 } \\
(2.36-4 \mathrm{~mm})\end{array}$ & $\begin{array}{c}\text { P3 } \\
(4-9.52 \mathrm{~mm})\end{array}$ \\
\hline \multirow{3}{*}{$\begin{array}{l}\text { Internal Bonding } \\
\qquad(\mathrm{MPa})\end{array}$} & $1: 2.75$ & $0.60^{\mathrm{Aa}}(22.78)$ & $0.55^{\mathrm{ABa}}(17.85)$ & $0.38^{\mathrm{Ba}}(31.49)$ \\
\hline & $1: 2.0$ & $0.67^{\mathrm{Aa}}(5.36)$ & $0.64^{\mathrm{Aa}}(14.98)$ & $0.25^{\mathrm{Ba}}(38.22)$ \\
\hline & $1: 1.15$ & $0.55^{\mathrm{Aa}}(11.52)$ & $0.51^{\mathrm{Aa}}(22.12)$ & $0.31^{\mathrm{Ba}}(6.82)$ \\
\hline \multirow{3}{*}{ MOR (MPa) } & $1: 2.75$ & $3.21^{\mathrm{a}}(18.86)$ & $1.73 \mathrm{bc}(38.81)$ & 1.53 bcd $(37.03)$ \\
\hline & $1: 2.0$ & $2.19^{\mathrm{b}}(19.67)$ & $1.47^{\mathrm{cd}}(26.97)$ & $0.78^{\mathrm{d}}(39.22)$ \\
\hline & $1: 1.15$ & $1.29^{\mathrm{cd}}(21.41)$ & $1.05^{\mathrm{cd}}(25.54)$ & $0.95^{\mathrm{cd}}(40.61)$ \\
\hline \multirow{3}{*}{$\operatorname{MOE}(\mathrm{MPa})$} & $1: 2.75$ & $2631^{\mathrm{a}}(33.02)$ & $930^{\mathrm{bc}}(50.87)$ & $709^{c}(67.38)$ \\
\hline & $1: 2.0$ & $1477^{\mathrm{b}}(49.68)$ & $813^{\mathrm{bc}}(35.08)$ & $248^{c}(43.97)$ \\
\hline & $1: 1.15$ & $658^{c}(21.09)$ & $529^{\mathrm{bc}}(44.16)$ & $420^{c}(50.81)$ \\
\hline
\end{tabular}

Means followed by same capital letter in the same column do not differ statistically by Tukey test $(\mathrm{p}<0.05)$. Means followed by the same lowercase letter in the same line do not differ; Values inside parentheses are the coefficient of variation (\%). MOR = modulus of rupture; $\mathrm{MOE}=$ modulus of elasticity; $\mathrm{P} 1$ = particles that passed through a $2.36 \mathrm{~mm}$ sieve but were retained in a $1.4 \mathrm{~mm}$ sieve; $\mathrm{P} 2$ = particles that passed through a $4 \mathrm{~mm}$ sieve but were retained in a $2.36 \mathrm{~mm}$ sieve; $\mathrm{P} 3$ = particles that passed through a $9.52 \mathrm{~mm}$ sieve but were retained in a $4 \mathrm{~mm}$ sieve. 
a network with an anchoring system of physical bonding that was enough to use a lower amount of cement without weakening the internal bonding.

Marzuki et al. (2011) suggested that the correlation between the amount of cement and internal bonding only takes place within a limit of a 1:2 wood/cement ratio, as a higher amount of cement could affect the compaction rate of the composite. This limit was not observed in vibro-compacted composites. Composites produced with 1:2.75 wood/cement ratio showed statistically similar average values when compared to composites with a lower amount of cement, as there is no compaction ratio when vibro-densification is applied without pressure.

According to Nazerian et al. (2011), the use of small particles in traditional wood-cement composites produced with pressure tends to show lower average internal bonding values than larger particle composites. A possible explanation for this behavior is the higher superficial area of smaller particles. A higher contact area between wood and cement can increase the mixture's contact with wood extractives which act as a cement setting inhibitor. Additionally, the amount of cement can be insufficient to cover the higher surface area of smaller particles, thus resulting in low internal bonding.

The use of the vibro-compaction method showed behavior different to that of the traditional method in relation to particle sizes. P1 and P2 composites had higher average values than P3 composites when the same wood/cement ratio was used. During the vibration process, P3 particles did not have as much free space to move inside the molds as smaller particles. The lack of movement resulted in less interaction between particles, and consequently, lower internal bonding values were observed.

At any wood/cement ratio, $\mathrm{P} 1$ and $\mathrm{P} 2$ composites met the minimum $0.4 \mathrm{MPa}$ internal bonding strength required for traditional pressed wood-cement composites (NCL, 2011), and also the 0.5 MPa standard determined by EN 634-2 (CEN, 2007).

Regarding the modulus of rupture property, there was only a statistically significant difference between composites with different wood/cement ratios when P1 particles were used (Table 3). Composites produced with smaller particles showed a direct correlation between MOR average values and the amount of cement in the mixture. This relation was the opposite of the one observed for pressed wood-cement composites in the literature.

Papadopoulos et al. (2006) suggested that the ideal wood/cement ratio for the MOR property for Oriented Strand Board (OSB) bonded with cement was $1: 2$ and could even be lower than 1:1.5. Ashori et al. (2012) also recommended a wood/cement ratio of 1:1.5 to reach higher average MOR values.

The different behavior of the MOR property among vibro-compacted composites and the traditional ones can be related to a lack of particle orientation. When a wood-cement mixture is submitted to pressure, wood particles will be oriented horizontally (board thickness) to a certain point. Oriented wood particles naturally have higher MOR values than cement material. Therefore, composites with higher wood content tend to show better average MOR values. In the case of vibro-compacted composites, there was no particle orientation in any direction, so the maximum load capacity of the composite is a function of the cement content. Therefore, composites with a higher amount of cement showed higher average MOR values.

Particle size effects observed in vibro-compacted composites was also different from those described in the literature for pressed composites. Nazerian et al. (2011) observed that if medium sized particles (similar to P2 particles) were used, the average MOR value was significantly higher than those of composites produced with smaller particles. This is due to improved particle contact, interlocking and the higher mat compaction rate. However, bigger particles decreased the bending strength, as porosity between particles increased.

When vibro-compaction densification was applied, better particle interlocking with low porosity occurred with P1 particles. However, the average MOR value of P1 composites was not higher if 1:1.5 wood/cement ratio was used. In this case, the amount of cement was inadequate to cover the higher surface area of the smaller particles, which resulted in MOR values being statistically equal to P2 and P3 composites.

Composites showed similar behavior for MOR and MOE properties. Wood/cement ratios only affected average MOE results of P1 composites. When small particles were used, composites with higher cement content had statistically higher MOE values than composites with 1:2 and 1:1.5 wood/cement ratios. This correlation was similar to the one found by Moslemi 
\& Pfister (1987) for traditional composites. Given that the MOE property indicates material stiffness, cement becomes the main variable in the process.

Particle size did not affect MOE property when the wood/cement ratio was 1:1.5. However, when the cement amount was higher, an effect on MOE could be observed. P1 composites with a 1:2.75 ratio had statistically higher average MOE values than composites made with bigger particles. Composites with a 1:2 ratio also showed higher MOE values for P1 composites when compared with P3 composites.

According to Olorunnisola (2009), one important variable control for composite properties was spacing between organic material and cement. In the vibro-compaction method, the use of smaller particles tends to create less free space inside the composite and consequently higher MOE values occur than in composites produced with bigger particles.

Static bending test results did not meet the minimum requirement of $9 \mathrm{MPa}$ for $\mathrm{MOR}$ and 3,000 $\mathrm{MPa}$ for MOE (NCL, 2011), as established for traditional pressed wood-cement composites.

The physical properties of composites produced with different wood/cement ratios and particle sizes are presented in Table 4.

An influence of all three different wood/cement ratios was observed on the water absorption properties after 2 and 24 hours of immersion in composites produced with similar particle sizes. Composites with a 1:2.75 ratio absorbed less water than those with a lower ratio, regardless of the particle size or immersion time.

Regarding particle size, the use of smaller particles showed higher average water absorption values after 24 hours of immersion than P2 and P3 composites with $1: 2.75$ and $1: 1.5$ ratios. There was no statistical difference for composites with different particle sizes when a 1:2 ratio was used.

A consensus still needs to be reached on the correlation between water absorption and wood/cement ratio in the literature. For example, Marzuki et al. (2011) analyzed the effect of different wood/cement ratios on the production of traditional composites with particle size similar to $\mathrm{P} 1$. In this case, water absorption was higher in the composites with a 1:2.5 ratio than a 1:1.75 ratio. On the other hand, when using a particle size close to P2, Fuwape \& Oyagade (1993) observed higher water absorption after 24 hours in composites with a $1: 1.15$ ratio than with a $1: 2.3$ ratio.

Particle size did not affect treatment means within the same wood/cement ratio, with the exception of those with a 1:1.5 ratio. $\mathrm{P} 1$ composites produced with low cement content absorbed more water than composites with bigger particles. Smaller particle size had higher surface area and needed a higher amount of cement to

Table 4. Average values for physical properties of wood-cement composites produced with different particle sizes and $\mathrm{wood} /$ cement ratios.

\begin{tabular}{|c|c|c|c|c|}
\hline \multirow[b]{2}{*}{ Physical properties } & \multirow[b]{2}{*}{ Wood/cement ratio } & \multicolumn{3}{|c|}{ Particle size } \\
\hline & & $\begin{array}{c}\text { P1 } \\
(1.4-2.36 \mathrm{~mm})\end{array}$ & $\begin{array}{c}\text { P2 } \\
(2.36-4 \mathrm{~mm})\end{array}$ & $\begin{array}{c}\text { P3 } \\
(4-9.52 \mathrm{~mm})\end{array}$ \\
\hline \multirow{3}{*}{$\begin{array}{c}\text { Water absorption after } \\
2 \text { hours }(\%)\end{array}$} & $1: 2.75$ & $16.69^{\mathrm{Ca}}(6.98)$ & $14.19^{\mathrm{Bb}}(9.86)$ & $14.77^{\mathrm{Bb}}(10.90)$ \\
\hline & $1: 2.0$ & $23.35^{\mathrm{Ba}}(9.58)$ & $23.46^{\mathrm{Aa}}(14.14)$ & $20.13^{\mathrm{Aa}}(15.61)$ \\
\hline & $1: 1.15$ & $37.10^{\mathrm{Aa}}(6.20)$ & $22.55^{\mathrm{Ab}}(7.41)$ & $19.07^{\mathrm{Ac}}(7.75)$ \\
\hline \multirow{3}{*}{$\begin{array}{c}\text { Water absorption after } \\
24 \text { hours (\%) }\end{array}$} & $1: 2.75$ & $19.43^{\mathrm{Ca}}(5.46)$ & $16.62^{\mathrm{Cb}}(8.46)$ & $16.97^{\mathrm{Bb}}(11.43)$ \\
\hline & $1: 2.0$ & $26.24^{\mathrm{Ba}}(8.13)$ & $23.44^{\mathrm{Ba}}(4.06)$ & 23.29 Аa (11.67) \\
\hline & $1: 1.15$ & $39.56^{\mathrm{Aa}}(9.53)$ & $26.22^{\mathrm{Ab}}(5.36)$ & $23.79^{\mathrm{Ab}}(7.71)$ \\
\hline \multirow{3}{*}{$\begin{array}{l}\text { Thickness swelling } \\
\text { after } 2 \text { hours (\%) }\end{array}$} & $1: 2.75$ & $0.36^{\mathrm{Aab}}(52.83)$ & $0.25^{\mathrm{ABa}}(50.15)$ & $0.12^{\mathrm{Bb}}(57.24)$ \\
\hline & $1: 2.0$ & $0.19^{\mathrm{Aa}}(32.36)$ & $0.20^{\mathrm{Aa}}(53.38)$ & $0.41^{\mathrm{Aa}}(53.57)$ \\
\hline & $1: 1.15$ & $0.58^{\mathrm{Aa}}(30.82)$ & $0.21^{\mathrm{Ba}}(70.80)$ & $0.25^{\mathrm{Ba}}(64.19)$ \\
\hline \multirow{3}{*}{$\begin{array}{l}\text { Thickness swelling } \\
\text { after } 24 \text { hours (\%) }\end{array}$} & $1: 2.75$ & $0.45^{\mathrm{Ab}}(27.74)$ & $0.34^{\mathrm{ABa}}(36.15)$ & $0.24^{\mathrm{Bb}}(54.68)$ \\
\hline & $1: 2.0$ & $0.36^{\mathrm{Ba}}(44.68)$ & $0.43^{\mathrm{ABa}}(45.14)$ & $0.77^{\mathrm{Aa}}(27.18)$ \\
\hline & $1: 1.15$ & $0.87^{\mathrm{Aa}}(14.73)$ & $0.29^{\mathrm{Ba}}(37.17)$ & $0.57^{\mathrm{Ba}}(44.51)$ \\
\hline
\end{tabular}

Means followed by same capital letter in the same column do not differ statistically by Tukey test $(\mathrm{p}<0.05)$. Means followed by the same lowercase letter in the same line do not differ; Values inside parentheses are the coefficient of variation $(\%) . P 1=$ particles that passed through a $2.36 \mathrm{~mm}$ sieve but were retained in a $1.4 \mathrm{~mm}$ sieve; P2 = particles that passed through a $4 \mathrm{~mm}$ sieve but were retained in a $2.36 \mathrm{~mm}$ sieve; $\mathrm{P} 3$ = particles that passed through a $9.52 \mathrm{~mm}$ sieve but were retained in a $4 \mathrm{~mm}$ sieve. 
be able to cover the wood. The results indicated that a wood/cement ratio of 1:1.5 was not enough to cover the $\mathrm{P} 1$ particle surface area.

After 2 hours of water immersion, P1 composites with 1:2.75 and 1:1.5 ratios showed statistically higher thickness swelling values than P3 composites. When a 1:2 ratio was used, there was no statistical difference for composites produced with different particle sizes. In the same way, there was no difference for thickness swelling for $\mathrm{P} 2$ composites, independent of wood/cement ratio.

After 24 hours, the P1 composite behavior was maintained when 1:2.75 and 1:1.5 wood/cement ratios were used. However, P1 composites had a statistically lower swelling than composites made with larger particle sizes for 1:2 ratio.

However, regardless of particle size or wood/cement ratio, all composites analyzed showed average thickness swelling after 24 hours of water immersion, being lower than the $1.5 \%$ limit required for commercial wood-cement composites made using the traditional press method (NCL, 2011).

\section{CONCLUSION}

Particle size affected physical and mechanical properties of vibro-compacted wood-cement composites. Particles that passed through a $2.36 \mathrm{~mm}$ sieve but retained by a $1.4 \mathrm{~mm}$ sieve had the ideal size for the vibro-compaction method, as they allowed better vibration and accommodation. As a consequence, composites with these particles had statistically higher MOR and MOE values than composites made with bigger particles.

The wood/cement ratio is an important tool for controlling the final density of vibro-compacted composites. A low amount of cement resulted in low density composites, whereas increasing the cement amount resulted in composites with higher average static bending values.

\section{ACKNOWLEDGEMENTS}

The authors thank the Instituto Nacional de Ciência e Tecnologia (INCT)/ Instituto Nacional de Pesquisa da Amazônia (INPA) for the supply of the wood material used in this research.

\section{SUBMISSION STATUS}

Received: 2 june, 2017

Accepted: 27 oct., 2017

\section{CORRESPONDENCE TO}

\section{Vinicius Castro}

Universidade Federal Rural do Semi-Árido UFERSA, Av. Francisco Mota, 572, Bairro Costa e Silva, CEP 59625-900, Mossoró, RN, Brasil e-mail: vinicius.castro@ufersa.edu.br

\section{REFERENCES}

Angyalossy-Alfonso V, Miller RB. Wood anatomy of the Brazilian species of Swartzia and considerations within the tribe Swartzieae. IAWA Journal 2002; 23(4): 359-390.

Ashori A, Tabarsa T, Sepahvand S. Cement-bonded composite boards made from poplar strands. Construction \& Building Materials 2012; 26: 131-134.

European Committee for Standardization - CEN. EN 310: wood-based panels: determination of modulus of elasticity in bending and of bending strength. Brussels: CEN; 1993a.

European Committee for Standardization - CEN. EN 317: aglomerado de partículas de madeira e aglomerado de fibras de madeira: determinação do inchaço na espessura depois da imersão em água. Brussels: CEN; 1993b.

European Committee for Standardization - CEN. EN 319: aglomerado de partículas de madeira e aglomerado de fibras de madeira: determinação da força da tensão perpendicular sobre a superfície plana da placa. Brussels: CEN; 1993c.

European Committee for Standardization - CEN. EN 634-2: cement-bonded particleboards: specifications: part 2: requirements for OPC bonded particleboards for use in dry, humid and external conditions. Brussels: CEN; 2007.

Frybort S, Mauritz R, Teischinger A, Muller U. Cement bonded composites: a mechanical review. BioResources 2008; 3(2): 602-626.

Fuwape JA, Oyagade AO. Bending strength and dimensional stability of tropical wood-cement particleboard. Bioresource Technology 1993; 44(1): 77-79. http://dx.doi. org/10.1016/0960-8524(93)90212-T.

Marzuki AR, Rahim S, Hamidah M, Ahmad Ruslan R. Effects of wood:cement ratio on mechanical and physical properties of three-layered cement-bonded particleboards from Leucaena lecocephala. Journal of Tropical Forest Science 2011; 23(1): 67-72.

Moslemi AA, Pfister SC. The influence of cement/wood ratio and type on bending strength and dimensional 
stability of wood-cement composite panels. Wood and Fiber Science 1987; 19(2): 165-175.

Nazerian M, Ghalehno MD, Gozali E. Effects of wood species, particle sizes and dimensions of residue obtained from trimming of wood-cement composites on physical and mechanical properties of cement-bonded particleboard. Wood Material Science \& Engineering 2011; 6(4): 196-206. http://dx.doi.org/10.1080/17480272.2011.601816.

NCL Industries Limited - NCL. Bison panel: cement bonded particle board. Abids: NCL; 2011. Catálogo.

Olorunnisola AO. Effect of husk particle size and calcium chloride on strength and sorption properties of coconut husk-cement composites. Industrial Crops and Products 2009; 29(2-3): 495-501. http://dx.doi.org/10.1016/j. indcrop.2008.09.009.

Papadopoulos AN, Ntalos GA, Kakaras I. Mechanical and physical properties of cement-bonded OSB. Holz als Roh- und Werkstoff 2006; 64(6): 517-518. http://dx.doi. org/10.1007/s00107-005-0092-6.
Parchen CFA, Iwakiri S, Zeller F, Prata JG. Vibro-dynamic compression processing of low-density wood-cement composites. European Journal of Wood and Wood Products 2016; 74(1): 75-81. http://dx.doi.org/10.1007/ s00107-015-0982-1.

Pereira D, Santos D, Vedoveto M, Guimarães J, Veríssimo A. Fatos florestais da Amazônia. Belém: IMAZON; 2010. $124 \mathrm{p}$.

Simatupang MH. Der Wasserbedarf bei der Herstellung zementgebunder Holzspanplatten. Holz als Roh- und Werkstoff 1979; 37(10): 379-382. http://dx.doi.org/10.1007/ BF02610947.

Steege H, Pitman NCA, Phillips OL, Chave J, Sabatier D, Duque A et al. Continental-scale patterns of canopy tree composition and function across Amazonia. Nature 2006; 443(7110): 444-447. http://dx.doi.org/10.1038/ nature05134. PMid:17006512. 